\title{
THE TREND OF USING SOCIAL MEDIA BY COLLEGE STUDENTS: A CASE STUDY AT SAMTSE COLLEGE OF EDUCATION, BHUTAN.
}

\author{
Lekh Raj Ghalley \\ Biology Teacher \\ Ministry of Education, Thimphu, Bhutan
}

\begin{abstract}
Social media usage by students has become so rampant in the recent years because of easy access to devices. It makes the communication and interaction with various people effective and easier all over the world. Therefore, this study was designed to provide information on the usage of social media by Samtse college students. The research survey was carried out at Samtse College of Education with Fifty undergraduate students taken randomly from the various disciplines. The findings from this study revealed that face book, twitters, MySpace, blogs, we chat, messengers, LinkedIn, you tube, window live, yahoo group, Google search, and flicker are the common sites prevailed among the students. The most popular sites of social media are googling and face book which are used by $100 \%$ of the college students. Google search, yahoo, email, We Chat and you tube are basically used for the academic purpose. Majority of the (88\%) students in the college used smart phones to access social networking sites while, $68 \%$ used laptop, $48 \%$ iPod/iPad and 54\% college computer. Above all, 54\% of respondents strongly agreed that social media plays vital role in learning and exploring for college student.
\end{abstract}

Keywords: College students, Social networking, Cyber bullying, learning tools

\section{INTRODUCTION}

Social media is a web-based service which provides an opportunity to an individual to create their own personal profile and connect with other users in the public forum (Khurana, 2015). Social media applications therefore allow users to create, edit and share new forms of textual, visual and audio content; and to categorize, label and recommend existing forms of content among each other. Currently, the social media has been using all over the world as it is cheap and fast way of accessing to the world. Majority of youth is shifting speedily from electronic media such as television viewers and radio listeners to the social media among all age of people.

According to Shabir (2014) social media is a set of internet-based application that allows the users to design and exchange the content in the close system. It is also defined as the platform for interaction among people in which they crate or share information and idea in virtual communities and internets (Govender, Yavisha, \& Krishna, 2013). All forms of social media depend on mobile and web-based technologies to form a collaborative platform where the users can share, create, discuss and modify the self-generated contents (Kulandairaj, 2014).

Since the last decade social media networks have created a phenomenon on the internet that has gained popularity over the last decade. These social media sites let those who use them create personal profiles, while connecting with other users of the sites. Users can upload photographs, post what they are doing at any given time, and send personal or public messages to whoever they choose to send. In this "information age," social media sites seem to be growing rapidly, especially among young adults (Pempek, Yermolayeva, \& Calvert, 2008). In particular, the large portion of population using social media is the college students. Smith (2009) suggested that almost all college students were using some form of social networking website. Selmon (2009) found that $72 \%$ of all college students have a social media profile with $45 \%$ of college students using a social media site at least once a day. However, the purpose of using social media differs among individual. Smith (2009) mentioned that the college students use social media services to keep in touch with friends and family. Surprisingly, $99 \%$ uses face books and $90 \%$ use e-mail for communication (Smith, 2009).

In fact, many youths get addicted to social media and miss out other important works such as studies and school work. As an individual one should be aware of the limit and should know what, when and how to use social media sites (Khurana, 2015).

\section{STATEMENT OF THE PROBLEM}

Social media usage by students is so rampant today because of easy access to devices such as smart phones, Iphones, I-pads, and lab-tops. Addiction to the usage of social media has increased in the recent times. It has been observed that students spend more time to social media than they do for 


\section{International Journal of Engineering Applied Sciences and Technology, 2019 Vol. 4, Issue 2, ISSN No. 2455-2143, Pages 40-47 \\ Published Online June 2019 in IJEAST (http://www.ijeast.com)}

their studies (Osharive, 2015) resulting to lower academic achievement, low self-perception and less interested in college oriented carriers (Maya, 2015).

The increased use of social media by youth across the world has several risks and consequences. The emerging issues over the decades are sharing too much information, posting of false information about themselves or others, exposure to fraudsters and marketers, and addiction to internet or social media use that have impacted negatively on their social, psychological and emotional well-being (Pempek et al., 2008). Other possible negative outcomes are exposure to cyber-bulling: allowing other access to personal information, offensive message, and harassment and sleep deprivation, which can lead to low academic performance (Finn, 2004).

Many parents and guardians are worried that their school going children are spending more time on face book and social media sites and less on study. Acheaw and Larson (2004) found that students are using social media sites on continue basis for chatting, downloading videos and music and only $6.4 \%$ of the students are using for the academic purpose. Hence, it was felt necessary by the author to understand how students are using social media sites at Samtse College of Education.

\section{RESEARCH QUESTIONS}

1. What are the usages of social media for college students?

2. What are the drawbacks of using social media?

3. Why does student visit social media sites?

\section{SIGNIFICANCE OF THE STUDY}

The finding of this study will inform the concern stakeholders and institutions about the young people's trend of using social media. It gives overview of how college students are using different forms of social media for several purposes and related risks on using social media. This study will also help the management and lecturers to select the common sites to disseminate information for professional development in the college.

\section{LITERATURE REVIEW}

\section{Historical background}

During the 1980's, home computers were becoming more common in the world and social media sites were becoming more refined. The Internet relays chats (IRCs), were first used in 1988 and were popularized into the '90s. The first popular social media site, Six Degrees, was created in 1997.The site enabled its users to upload a profile and make friends with the other users (Hendricks, 2013). By 2006, face book and twitter both became available to users throughout the world. These sites still remain as the most popular social network on the Internet.
Given the history of social media, there are still many social media sites appearing on the Internet. The most famous social media site now is face book. It was invented by Mark Zuckerberg who launched a website called "The Face book" on February 2004. The website was named from a printed manual that was handed out every year in Harvard University containing the pictures of all students and staff of the university, so they can get to know each other (Ilagan, 2013).

After the success in launching the website, face book had been able to expand as a company by opening its share of the company to the market, allowing investors to invest in the company and by venture capital. Because of that, face book received a lot of offers to be bought out from companies such as google and yahoo and other top companies in the market (Singer, 2010). Social media had become a big part to every people loves. Nowadays, almost all people have social media accounts. Social media sites have been used in almost all areas from business markets to academics. Students had used social media sites as tools to help them upload lecture notes to groups and relay messages from teachers to their classmates. Social media sites especially, face book, let people interact with each other. It helps with almost everything from messaging to video calls. Thus, the research has found social media to be effective for students' academic (Ilagan, 2013).

\section{Social media in bhutan}

Bhutan is a small landlocked country sandwiched between two giant countries, China from north and India from south. It was almost totally isolated from the rest of the world until 1970's. The internet and television arrived only in 1999. Although it stepped into the internet age very late, the social media websites such as face book and twitter have caught on rapidly. According to Bhutan information and media impact study (2013) the number of internet subscribers has increased from 5,726 in 2008 to 15,353 in 2012

In recent years, social media has gained popularity with an increasing number of Bhutanese blogging, visiting popular social networking sites like face book and twitter for news and information, interaction, and discussion among others. Sangay Khandu, Member of Parliament from Gasa constituency mentioned during the first social media conference in 2011 that Bhutan has had no study on social networking sites but it may have 33,340 face book users, age 18 and above who live in Bhutan. According to face book statistics and a google search leads one to a number up to 37,180 face book users from Bhutan, which equals to 74 percent of internet users in Bhutan via kuensel. For example, the Prime Minister of Bhutan has over 46000 followers in face book, and nearly 27000 followers in twitter - quite a significant number in a country with a population of just over seven lakes. With smart phones and $3 \mathrm{G}$ network reaching out to even remote areas, social media is becoming more and more accessible in Bhutan.

Rabgay (2016) stated in his study that face book was the most popular in Bhutan and failed to consider that other 


\section{International Journal of Engineering Applied Sciences and Technology, 2019 Vol. 4, Issue 2, ISSN No. 2455-2143, Pages 40-47 \\ Published Online June 2019 in IJEAST (http://www.ijeast.com)}

type of social networking sites will be used along with face book. Till date, no one has carried out research on social media usage in the country and the data base in this area is missing. Therefore, this study may serve to create data base for the future researchers.

\section{Importance of using social media in education}

Social media is a new forum that brings people to exchange ideas, connect with, relate to, and mobilize for a cause, seek advice, and offer guidance. Social media has removed communication barriers and created decentralized communication channel and open the door for all to have a voice and participate in online discussion (Amedie, 2015). Social networking sites help students do significantly better in school, primarily through connecting with each other on school assignments and collaborative group projects outside of class. According to Amedie (2015), some school are successful in the of use social media as teaching tools, which has the benefit of reinforcing skills in English, written expression, and creativity. Due to the accessibilities of social media, social media provides an adequate opportunity for youths to explore their interest and problems with similar individual, academic support, while strengthening online communication skills and knowledge. Wang et al., (2011) also cited in their work that students those who are reluctant to participate in the class can also participate in online group discussion. Thus, social media helps students to enhance learning by writing to real audience (Brydolf, 2007).

Markwei and Appiah (2016) cited in their study that U.S. study explored the use of social networking Sites (SNS) as a source of information for teens. It investigated the question-asking-and-answering practices of 158 high school students on popular social networking sites. The findings revealed that the participants asked questions to satisfy 28 categories of information needs. The majority of the questions (76\%) were school related, suggesting that social media can be a major source of information for answering the questions teens care about, especially school-related information.

Aforementioned evidences advocated that social media plays the tremendous role in enhancing learning to young people across the globe.

Impact of social media sites on students

American college students have great interest on social media. Over the years, the use of social media has increased drastically. However, the use of social media also produced both negative and positive consequences. There was heated topic of debate on social media that have a negative effect to students and leads to lower their academic performance (Ilagan, 2013). According to Khan (2011) nearly $55.4 \%$ of the total population from people ranging in the age group 15 to 25 use social networking sites and the same range of age group users also seek social networking sites as a medium of entertainment. In terms of gender division, male users are more as compared to female users wherein male users generally derive knowledge-based information from these sites. It focuses on the fact that most of the youth uses these sites due to influence of their friends and just because their friends have been using and accessing these sites.

Another US study also stated that students are using electronic media in the class (Jacobsen \& Forste, 2011). This multi-tasking is very detrimental to the performance of students by increasing distractions. Qingya, Chen, Wei, and $\mathrm{Yu}$ (2011) also stated that social media is becoming very dangerous as it creates mode of procrastination, thereby students failed to complete their home works on time. Therefore, it is very crucial for student to know the limit while using social media in our day to day life. There is a saying in Buddhist scripture "that a person who knows the limit while using things are considered as wise."

\section{RESEARCH METHODOLOGY}

A survey approach was employed in this study. The sample of this study was 50 active students (25 males and 25 females) from Samtse College of Education.The respondents were collected randomly from B.Ed and Post Graduate Students in the campus.

The written questionnaire was created by the principal researcher with some questions adapted from (Seaman, 2013: Sponcil \& Gitimu, 2010) and (Kettle, Gilmartin, Mary, Corcoran, Byrne \& Sun, 2016). The questionnaire was divided into two sections. Section A gathered respondent's background information such as gender, program of study and year of study. Section B consists of questions with regard to students' use of social media network.

Data analysis was carried out using Microsoft Excel. Excel database was created. An assessment is conducted to test the reliability and validity of the measurement used. Every response item on the questionnaire were carefully entered under the questions header in the Microsoft excel when the entire survey questionnaires was completed.

\section{LIMITATION OF THE STUDY}

1. Study was conducted with a small sample and the findings may not have represented the whole population. However, the manipulation of the data was strictly prohibited in this study.

2. Finding may be or may not be good enough as the respondents have provided limited views on questions. May be they are not comfortable to share some sensitive issues. Other reason could be, having poor in written language some respondents could not write their incidences in black and white.

\section{FINDINGS}

The usage of social networking sites by the students in the college 


\section{International Journal of Engineering Applied Sciences and Technology, 2019 \\ Vol. 4, Issue 2, ISSN No. 2455-2143, Pages 40-47 \\ Published Online June 2019 in IJEAST (http://www.ijeast.com)}

The results revealed that the college students are very active on the social media accessing as far as 20 different sites for social, academic and entertainment purposes. The most accessed site include face book, and other social networking
To determine the uses and gratifications that students derive from using SNS, respondents were asked to indicate the purposes for which they used social media. The results showed that the respondents primarily used social media for

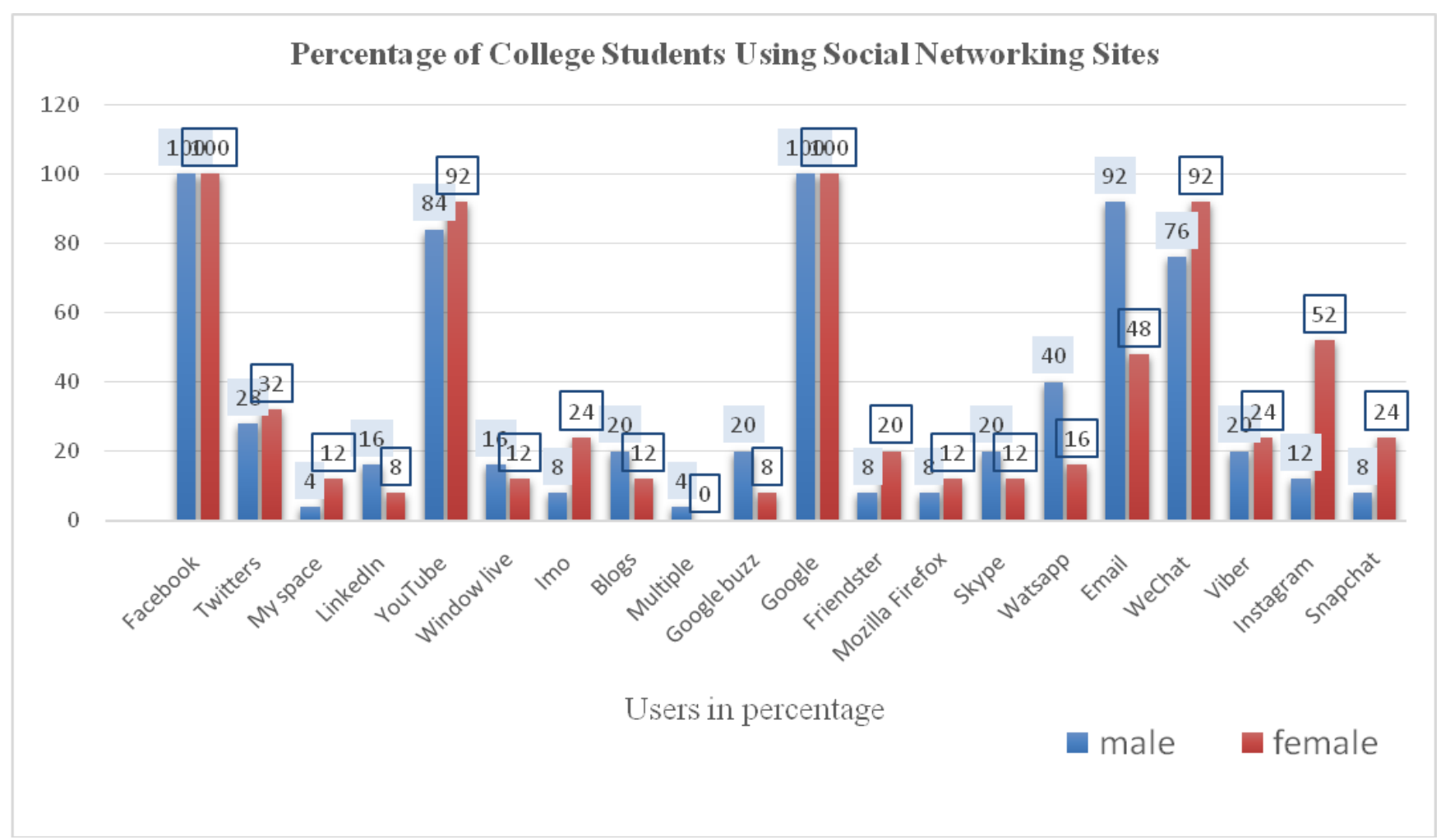

sites include twitters, MySpace, blogs, we chat, messengers, LinkedIn, youtube, window live, industries websites, yahoo group, google search, emo, viber, instagram, snap chat, skype, whatsapp and flicker. The reasons cited by most of the respondents for accessing these sites include social - to maintain their friendship, stay in touch with their family members; entertainment - to share information and updates news, to upload photos to earn likes and comments; and academic. The frequency of usage of these sites varied with "face book and google topping the list (100\%)" followed by wechat $(92 \%$ female and $76 \%$ male), you tube $(92 \%$ female and $84 \%$ male), email ( $42 \%$ female and $92 \%$ male), whatsapp (16\% female and $40 \%$ male) and twitter (32\% female and $26 \%$ female) and so on. Emo, snap chat and firebox mozilla were used least by college students. These data evidently depicted that majority of female students used we chat and you tube (92\%) while male students seem to be more aligned with email. However, the most favored social for both the gender is face book (100\% each).

Figure1. Social networking sites (SNS) used by the college students

\section{The purpose of using social media}

staying connected with friends and family and also to gather information of all round context. Other purposes included gathering information and staying connected with friends and family (98\%), making update about games and sports and also about online games $(78 \%)$, business $(24 \%)$, finding or searching new friends (80\%), sharing opinion (58\%), multimedia includes listening music, watching video, movies, TED talks, tutorial, etc (82\%), sharing experiences $(44 \%)$, and only $(2 \%)$ of college students spent on reading news, chatting and as a meant for escaping boredom.

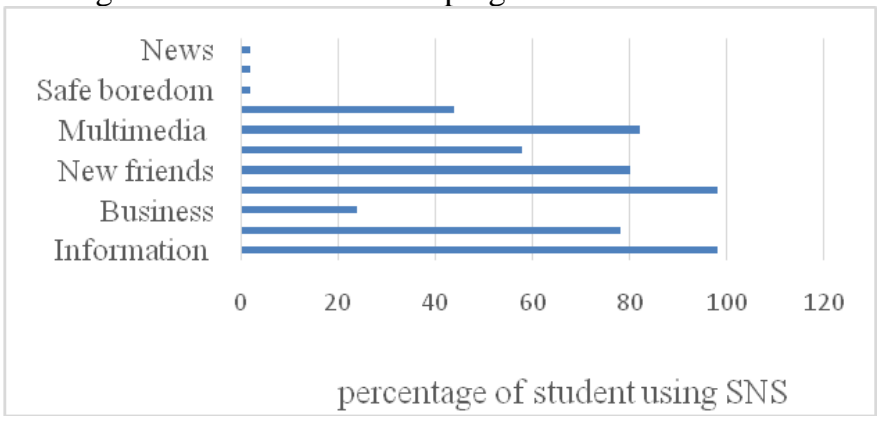

Figure 2. Purpose of using SNS

Access to social media 


\section{International Journal of Engineering Applied Sciences and Technology, 2019 \\ Vol. 4, Issue 2, ISSN No. 2455-2143, Pages 40-47 \\ Published Online June 2019 in IJEAST (http://www.ijeast.com)}

There were two ways through which students can accessed social media in the college campus. Eighty percent of the students were using individual net package in their phone to access social media and $49 \%$ were using college computer lab to access free WIFI service of the college. These were two ways students used in the college campus to access social media for social, academic or entertainment purpose.

\section{Devices used to access social media}

The findings of the study further revealed that the respondents accessed social media through various technological devices including smart phones (88\%), laptops (48\%), college computer (54\%), Ipod/Ipad (8\%) and tab $(2 \%)$.

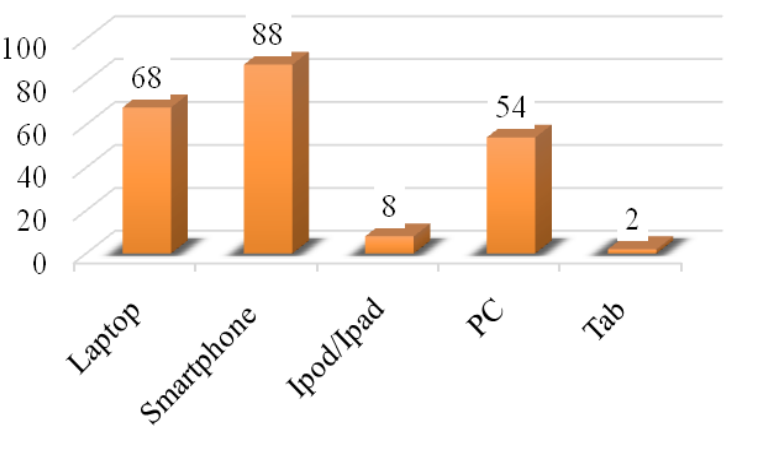

Figure 3. Devices use to access social media

\section{Time spent on social media in a day}

Respondents were also asked to indicate how many hours they spend each day using SNS. Sixty-four percent of the college students admitted that they spent 2-6 hours per day to check a social media site, $20 \%$ spent more than $6-12$ hours, $8 \%$ spent $13=24$ hours and $8 \%$ spent less than 1 hour. Results showed that some students are addicted on using social media.

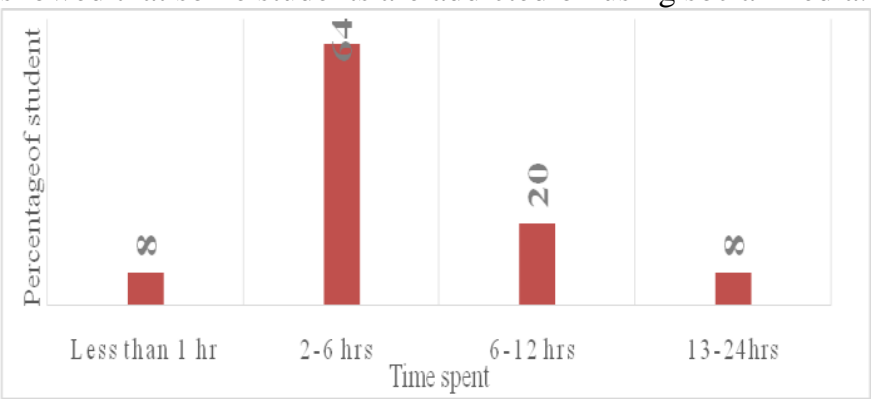

Figure 4. Time spends on SNS in a day

\section{Importance of social media in education}

$54 \%$ of respondents strongly agreed that social media plays vital role in learning and exploring for college students. A significant majority of $38 \%$ just agreed for considering social media boon to student in college. However, there were minor respondents $(2 \%)$ who disagreed.

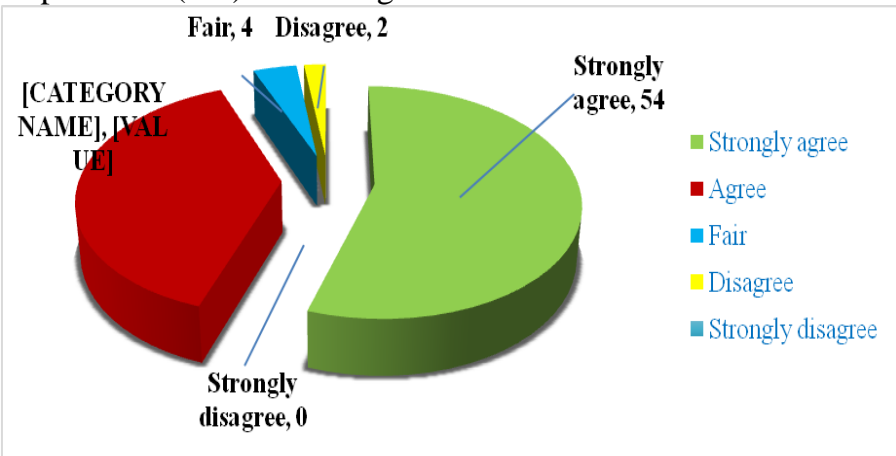

Figure 5. Importance of SNS in education

Negative impacts of using social media

Table 1. Risk of using social media

\begin{tabular}{|c|c|c|}
\hline \multicolumn{3}{|c|}{$\mathbf{N}=\mathbf{5 0}$} \\
\hline Nature of problem & Frequency & $\begin{array}{l}\text { Percentage } \\
(\%)\end{array}$ \\
\hline Miscommunication & 28 & 56 \\
\hline Time consuming & 16 & 32 \\
\hline $\begin{array}{l}\text { Influence to mischievous } \\
\text { activities }\end{array}$ & 20 & 40 \\
\hline Dependent on social media & 32 & 64 \\
\hline Copy-paste work & 47 & 94 \\
\hline Limit critical thinking & 49 & 98 \\
\hline Make student lazy & 12 & 24 \\
\hline Addiction & 25 & 50 \\
\hline Lack creativity & 37 & 74 \\
\hline Online bullying & 34 & 68 \\
\hline
\end{tabular}

While using social media respondents have encountered the lists of risks. The results at (Table 1) evidently revealed that social media is very instrumental for young people. Social media feeds youngsters with every required information, thus they tend to become dependent in every context.

\section{Cyber bulling incidents}

Table 2.Cyber bulling incidences in the college campus 


\begin{tabular}{|l|l|l|l|l|}
\hline \multicolumn{5}{|c|}{ N=50 (Male 25 \& female 25) } \\
\hline & \multicolumn{2}{|l|}{ Male } & \multicolumn{2}{l|}{ Female } \\
\hline Incidents & frequency & $\begin{array}{c}\text { Percentage } \\
(\%)\end{array}$ & Frequency & $\begin{array}{c}\text { Percentage } \\
(\%)\end{array}$ \\
\hline Fake profile & 7 & 28 & 2 & 8 \\
\hline $\begin{array}{l}\text { Offensive } \\
\text { message }\end{array}$ & 9 & 36 & 4 & 16 \\
\hline Harassment & 10 & 40 & 1 & 4 \\
\hline $\begin{array}{l}\text { Transferring } \\
\text { spy and virus }\end{array}$ & 4 & 16 & 5 & 20 \\
\hline
\end{tabular}

In Samtse College of Education, the most popular social media sites were face book and Google (100\%) followed by we chat ( $92 \%$ female and $76 \%$ male), you tube (92\% female and $84 \%$ male), email (42\% female and $92 \%$ male), whatsapp ( $16 \%$ female and $40 \%$ male), twitter $(32 \%$ female and $26 \%$ female) and emo, snap chat and firebox mozilla were used least by college students. This study also found that the respondents accessed social media via smart phones, desktop in the college laboratory, iPads, tablets and laptops. Due to the advancement in modern technologies, $88 \%$ of respondents were using smart phones to access social media and $48 \%$ of are using personal (owned) computers, more than half of the college students $(54 \%)$ are using computers from college computer lab. This finding unswervingly inferred that there are significant numbers of students in the college who are dependent on college computer to do their academic or other works.

This study also reports on some negative encounters

The survey has addressed significant incidents experienced by the respondents in the college campus while using social media. The results divulged that $28 \%$ (female) and $8 \%$ (male) had experienced themselves being threatened or deceived by someone with faked identity, 36\% (female) and $16 \%$ (male) had experienced mean, hateful or filthy messages from other users and 40\% (female) and 4\% (male) had also experienced harassment. Another $16 \%$ (female)and $20 \%$ (male) respondents had encountered spy and virus being transfer to their devices while logging to links in social media.

\section{DISCUSSION}

The findings of this study suggested that almost all college students were using some form of social networking website. This is significant since Lenhart et al. (2010) found that $71 \%$ of young adults have a Face book account. The current study indicated that Face book was the social network websites of choice, with $100 \%$ of college students using Face book. This finding corresponded with research by Lenhart et al. (2010) which found that Face book is the most popular form of social media. Google was also used by all (100\%) students in the campus to gather information in any context. There are many other types of social media sites which were found using by the college students. Several reasons were given as to why college students were using social networking websites. The most important reason given was to communicate with family and friends, information processing and socializing. Entertainment and boredom were also prominent reasons for use social networking sites. These findings are supported by Sheldon (2008) who found that students use Face book and other websites to pass time, be entertained, and maintain existing relationships with others. It seemed that college students were using social media sites to communicate with others as well as to occupy free time when they were bored. and cyber bullying in the participants' use of social media, such as fake profile, harassment, offensive messages, and transferring spy and virus. Hitherto, cyber bulling has not become a major issue among the student in the campus but the study has revealed some forms of cyber bulling being encountered by the college students. Khurana(2015) and Markwei and Applan (2016) also intervened into similar situation and had found that increasingly youth were encountering cyber-bulling in different forms such as fake identity, harassment and smeared messaging.

The findings also reveal that $8 \%$ of the respondents spent less than one hour in a day using social media and that $20 \%$ of them spent 6-12 hours. The maximum respondents comprise $64 \%$ of them spent 2-6 hours in a day. Surprisingly, there are $8 \%$ of respondents that spent 13-24 hours in a day. Students spending this much time on social media will have less available time for schoolwork, which can affect their academic performance (Markwei \& Applan, 2016).

Since the majority $(60 \%)$ of respondents reported to have agreed on using social media social media sites for learning in the college as it is vital for the college to integrate such facilities in the education curriculum. Besides other social reasons, $100 \%$ of respondents used Google search engine to gather information for project, assignment, presentation, and also to collect email from respective sender. These days, YouTube has gained the popularity among student for downloading videos, tutorials and speeches from an eminent persona. Thus social media play an important role for college student when it comes to entertainment, relationship, information and socializing

\section{RECOMMENDATION}

This research indicated that most college students would prefer to use social media and spend countless hours checking social media sites. Social networking is definitely affecting students' efficiencies and impedes their academic 


\section{International Journal of Engineering Applied Sciences and Technology, 2019 Vol. 4, Issue 2, ISSN No. 2455-2143, Pages 40-47 \\ Published Online June 2019 in IJEAST (http://www.ijeast.com)}

performance in the college. Hence, educators need to be concerned about these problems and try to find better ways to solve these problems.

Social Networking Sites enables the people to raise their voice against social issues which is an important right of the people in a democratic society. Provide maximum possible ways for this service. All the youths should be aware of their right and explore the opportunities provided by Social Networking Sites in this respect.

Those platforms which misguide the students should be restricted and there should be watchdog software in the server to hunt the students who are using these sites or these sites may be permanently blocked or a specific timing should be given to the students in the university hours for the use of social media websites. There should extra-curriculum and awareness forum in the college regarding the instruction about the positive usage of social media sites.

\section{CONCLUSION}

This research has revealed that college students are using various forms of social media in the college. The most popular sites of social media are google and face book which were used by all students for gathering information and keeping connected with friends respectively. Social media offers young people several benefits and opportunities in life, which includes accessing to information, development and maintenance of personal and professional relationship and fun. It is also a platform for experimentation, self-expression and identity formation. This study viewed benefits, positive and negative impacts of social networking sites and how the social networking sites influence youth in their study. The trends of using social media by the students are clearly stated in this paper. Overall, students are prolifically using social media in the college for social, psychological and professional development except few incidences of cyber bullying experienced by college students.

\section{REFERENCES}

[1] Acheaw., M., O., \& Larson., A., G. (2016). Use of social media and its impact on academic performance of tertiary instuition students: A case study students of Koforidua Polytechnic, Ghana. Journal of education and practice, 6(6).122-129.

[2] Amedie, J. (2015). The impact of social media on society. Advanced writing: Pop Culture Intersections. Retrieved from http://scholarcommons.scu.edu/engl_176/2

[3] Brydolf, C. (2007). Minding myspace: Balancing the benefits and risks of students'online social networks. Education Digest, 73(2), 4.
[4] Finn, J. (2004). A survey of online harassment at a university campus. Journal of International Violence, 19(4), 68-481.

[5]Govender., Y., R.,\& Krishna, K. (2013) The relationship among certain youths' variables and sheir social media browsing behaviour.African Journal BusinessManagement 7(25): 2495-2499.

[6] Hendricks, D. (2013, May). The complete history of social media: then and now. Retrieved from http://smallbiztrends.com/2013/05/the---complete--history---of--- social-- -media---infographic.html.

[7] Ilagan, F, T. (2013). An Analysis on the impact of Social Media on College Students' Academic Performance. De La Salle University-Manila.

[8] Jacobsen, W. C., \&Forste, R. (2011). The Wired generation: academic and social outcomes of electronic media use among university students.

[9] Kettle,P., Gilmartin, N., Mary, P., Corcoran., Byrne, D.,\&Sun, T. (2016).Time Well Spent? A survey of student online media usage. Department of Sociology, Maynooth University. Retrieved from https://www.maynoothuniversity.ie/.../SOCIAL\%20 MEDIA\%20SURVEY\%20FINAL.

[10] Khan, S. (2011). The impact of social networking websites on students. Journal of social science 5:56-57

[11] Khurana, N. (2015).The impact of social networking sites on the youth. $J$ Mass Communication Journalism 5: $285 . \quad$ doi:10.4172/21657912.1000285

[12] Kulandairaj, D., A. (2014). Impact of social media on the. International Journal of Technical Research and Applications, 2(8), 22-28.

[13] Maya,K, G., (2015). Achievement scripts, media influences on blacks student' academic performance, self- perceptions and carrier interests. Journal of Black Psychology, 42(3) pp,195- 20.DOI:10.1177/0095798414566510.

[14] Markwei, E, D.,\& Appiah, D. (2016). The impact of social media on Ghanaian youth: A Case study of the imaandMaamobi communities in Accra, Ghana. JRLYA: 7(2).

[15] Mensha, S, O.,\&Nizam, I. (2016). The impact of social media on students 'academic performance-A case study of Malaysia tertiary intuition. International journal of education, leaning ad training. $\quad 1 \quad$ (1). $\quad$ DOI: 10 24924/ijelt/2016.11/v1.iss1/14.21

[16] Osharie, P. (2015). Social media and academic performance of students, conference paper of January 2015.Retrieved September, 2016 from https://www.researchgate.net/publication/273765340 
[17] Pempek, T. A., Yermolayeva, Y. A., \& Calvert, S. L. (2008). College students' social networking experiences on facebook. Journal of Applied Developmental Psychology, 30(3), 227-238. doi: 10.1016/j.appdev.2008.12.010

[18]Salmon, G. (2005). E-moderating: The key to teaching and learning online. New York:RoutledgeFalmer.

[19] Shabir, Y. M. (2014). The impact of social media on youth: A case study of Bahawalpur city. Asian journal of social sciences \& humanities, 3(4), 132-51.

[20] Singer, R. (2010). Facebook \& OSS: Briefhistoryoffacebook. Retrieved August 22, 2013, $\quad$ From http://terpconnect.umd.edu/ sqin/group/bgfb.html

[21] Smith, B. V. (2009). Use of online educational social networking in a school environment

(Unpublished master's thesis). North Carolina State University, Raleigh, NC.

[22] Wang., Qingya., Chen., Wei., \& L.,Yu, (2011). The effects of social media on college students. Retrieved fromhttp://scholarsarchive.jwu.edu/mba_student/5 